\title{
A histological study of the effect of chronic gastritis on gastrin cell distribution in the human stomach
}

\author{
J. M. SlOAN, K. D. BUChANAN, R. J. McFARLAND, P. TITTERINGTON, AND \\ J. C. SANDFORD
}

From the Departments of Pathology and Medicine, Queen's University, Belfast, UK

SUMMARY To determine the effect of varying degrees of gastritis on the distribution of immunoreactive gastrin cells 38 partial gastrectomy specimens have been studied. Routinely stained histological sections of mucosa were compared with serial and adjacent sections stained by specific immunohistochemistry using peroxidase and fluorescent techniques. While chronic superficial gastritis had no obvious effect, mild atrophic gastritis was associated with an uneven distribution of gastrin cells which became more marked with increasing severity of gastritis. In the region of intestinal metaplasia gastrin cells were almost totally absent.

Small numbers of gastrin cells were found within areas of pseudopyloric metaplasia in the fundus, a region where those cells are not normally seen. Similarly, gastrin cells were detected within regenerative gastric polypi in both antrum and fundus.

Chronic gastritis is a common condition found in association with gastric carcinoma and gastric and duodenal ulceration (Morson, 1955; Gear et al., 1971). It is frequently found in patients with no gastrointestinal symptoms (Joske et al., 1955) and is reported to be increasingly prevalent with advancing age in a representative sample of the working population (Siurala et al., 1968). Morson (1955) also noted an increased incidence of intestinal metaplasia in older people.

Since McGuigan (1968) demonstrated gastrincontaining cells in the pyloric antrum, numerous studies have been carried out to define the distribution of these cells and, more recently, to quantitate the cells in normal and disease states. Among the quantitative studies that have been carried out, Ganguli et al. (1974), Asnaes et al. (1976), and Creutzfeldt et al. (1976) have used gastric mucosal biopsies while Keuppens et al. (1978), Delaney et al. (1978), and Stave and Brandtzaeg (1976) have studied gastrectomy specimens.

Some of these authors (Asnaes and Keuppens) have commented upon the diminished numbers of immunoreactive gastrin cells in the presence of local mucosal gastritis, and we have noted similar findings. In view of the widespread prevalence of chronic gastritis we undertook to determine the effect of varying degrees of this disorder on the distribution of gastrin cells within gastric mucosa.

Received for publication 18 September 1978

\section{Material and methods}

Immediately after removal from the body 38 partial gastrectomy specimens were fixed in formol saline solution or in Bouin's fixative. After fixation at least five longitudinal strips of mucosa were taken from each specimen. The strips were obtained from non-ulcerated and non-cancerous mucosa on the lesser and greater curvatures and anterior and posterior walls. Both antral and fundal mucosa was included if present. Further samples were also taken from any areas of flat or atrophic mucosa. Mucosal strips were often embedded in the form of a 'Swiss roll' in order to facilitate examination of a large area on a single slide.

The tissue was dehydrated and embedded in paraffin wax as for routine histological processing; $5 \mu$ paraffin sections were dewaxed and stained using haematoxylin and eosin. Adjacent or serial sections were stained for immunoreactive gastrin cells using specific immunohistochemistry. The location and degree of gastritis, if any, in the mucosa was assessed on the $H$ \& E section, and the effect of the gastritis on immunoreactive gastrin cells was determined in the adjacent specifically stained section. The morphology of the sections was similar, and it was quite easy to identify localised areas in the specifically stained sections even when immunofluorescence was used by comparing them with the corresponding $H \&$ E section. Gastritis was assessed according to the criteria of Whitehead et al. (1972). 
Immunohistochemical identification of gastrin cells was carried out using either the peroxidase anti-peroxidase bridge technique (Taylor, 1974) or indirect immunofluorescence 1 . Both provided consistent results. The peroxidase method entails the use of soluble horseradish peroxidase rabbit antiperoxidase complexes ${ }^{2}$ (Sternberger et al., 1970). Immunoperoxidase has the advantages of providing a permanent preparation, and when the section is counterstained with toluidine blue, orientation of the stained cells in relation to the remainder of the tissue is obvious. The immunofluorescent technique is, however, quicker and involves no potential carcinogens. No rapid fading of fluorescence was experienced and there was ample time in which to study and photograph sections shortly after staining.

Antibody to gastrin was prepared in New Zealand white rabbits using synthetic human gastrin (ICI) conjugated to ovalbumin using glutaraldehyde and emulsified in complete Freund's adjuvant (Ardill, (1973). Under radioimmunoassay this antibody reacts with both gastrin (G-17) and big gastrin (G-34) on an equimolar basis. Cross-reaction with cholecystokinin-pancreozymin was detected under radioimmunoassay conditions, cross-reactivity occurring in a ratio of 10000:1 cholecystokinin: gastrin on a weight basis though this is not directly applicable to immunohistochemical conditions.

Numerous controls were carried out during the staining procedure. When phosphate-buffered saline was substituted in turn for each step or when non-immune serum was used the results were consistently negative. Gastrin cell staining was completely blocked by pre-absorbing the antibody with gastrin. No diminution or blocking of staining was noted when the antibody was incubated with secretin, insulin, glucagon, or somatostatin.

No attempt was made accurately to quantitate the gastrin cells or to compare numbers present in different specimens. Where possible, each specimen acted as its own control, as suggested by Delaney et al. (1978), the concentration of gastrin cells in histologically normal areas being compared with areas in the same specimen showing gastritis. While minor differences may have been missed, the effect of significant degrees of gastritis on the local gastrin cell population was very marked and did not necessitate accurate quantitation.

Table 1 shows the conditions for which partial gastrectomy was carried out. None of the patients studied suffered from pernicious anaemia.

${ }^{1}$ Reagents supplied by Behringwerke AG, Marburg/Lahn, West Germany

'Supplied by Dakopatts, Denmark through Mercia Diagnostics, Watford, Herts
Table 1 Conditions for which partial gastrectomy was carried out

\begin{tabular}{lc}
\hline Disease process & No. of patients \\
\hline Gastric ulcer & 8 \\
Antrectomy for recurrent duodenal ulcer & 10 \\
Cardio-oesophageal carcinoma & 5 \\
Gastric carcinoma & 7 \\
Gastric leiomyoma & 1 \\
Gastric polypi & 5 \\
Stomach adherent to pancreatic carcinoma & 2 \\
\hline
\end{tabular}

Table 2 Number of specimens examined showing each of the various degrees of mucosal pathology

\begin{tabular}{lc}
\hline Pathology & No. of specimens \\
\hline No gastritis & 6 \\
Chronic superficial gastritis & 8 \\
Atrophic gastritis & 24 \\
Gastric atrophy & 0 \\
\hline
\end{tabular}

\section{Results}

In five of the specimens no antral mucosa was present. In the remainder both antral and body mucosa was seen. Table 2 shows the most severe degree of gastritis found in the specimens examined.

The effect of mucosal gastritis on local immunoreactive gastrin cell concentration was consistent throughout all specimens.

In histologically normal antrum, gastrin cells were found mainly in the lower middle third of the mucosa and in the basal third. The base of the gastrin cell lies against the basement membrane of the gland. There was an uneven distribution of cells within the zone of the mucosa described above. This was most obvious at the base of mucosal folds (Fig. 1).

The presence of active chronic superficial gastritis with increased numbers of inflammatory cells in the lamina propria, degeneration of surface epithelium, and inflammation of gastric pits had no marked effect on the numbers of gastrin cells detected provided there was no significant atrophy of glandular tubules (Fig. 2).

Whitehead et al. (1972) emphasise the difficult line of demarcation between superficial gastritis and early atrophic gastritis, but where inflammation extended deeply into the mucosa around the glandular tubules and was accompanied by even mild tubular atrophy, that is, in the presence of mild atrophic gastritis, the uneven distribution of gastrin cells became more accentuated, resulting in a patchy distribution. Areas in which gastrin cell numbers were diminished corresponded with patches 
of more severe inflammation and glandular atrophy (Fig. 3).

This patchy distribution increased in more severe atrophic gastritis, and in the presence of intestinal metaplasia the number of gastrin cells was markedly reduced and only occasional cells were detected (Fig. 4). This observation applied regardless of whether the metaplasia was extensive or was present as an isolated island.

The distribution of gastrin cells in the transitional zone between antrum and fundus is shown in

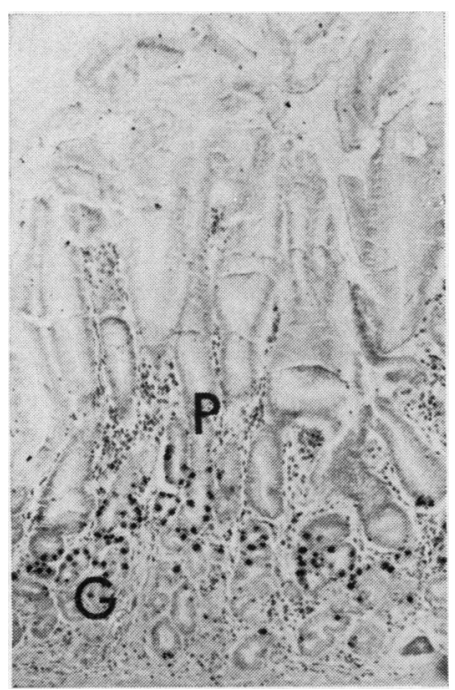

Fig. 1(a) Normal antral mucosa showing gastrin cells at base of pits $(P)$ and upper part of glandular zone $(G)$. Immunoperoxidase. $\times 100$.

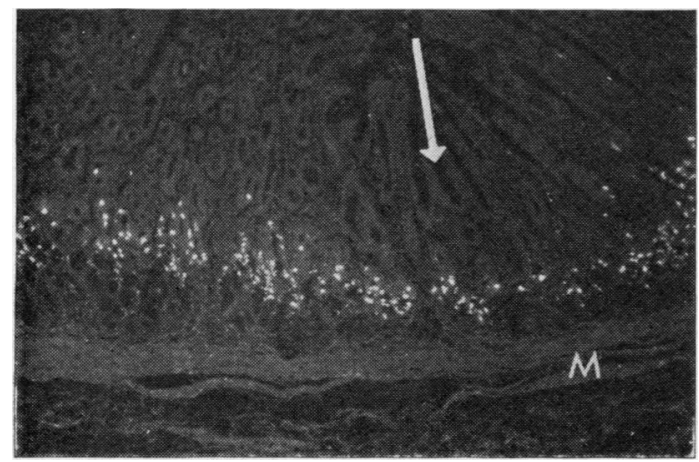

Fig. 1(b) Normal antral mucosa. Uneven distribution of gastrin cells at base of mucosal fold (arrowed).

Muscularis mucosae (M). Immunofluorescence $\times 32$.

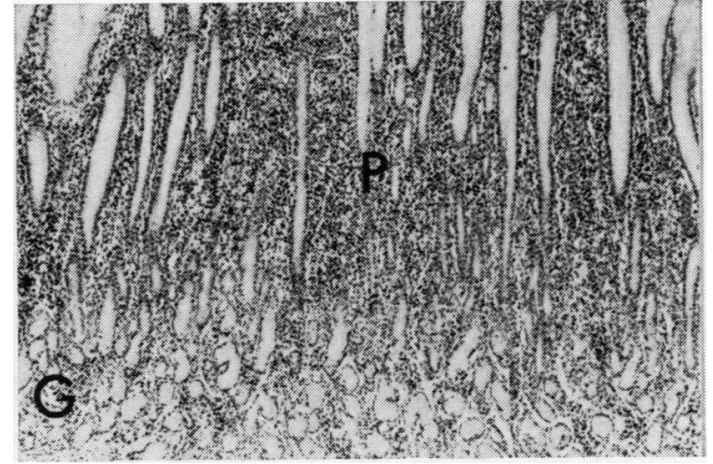

Fig. 2(a) Chronic superficial gastritis in antral mucosa. Heavy inflammatory cell infiltrate among gastric pits $(P)$. No marked atrophy of glandular zone $(G)$.

Haematoxylin and eosin $\times 80$.

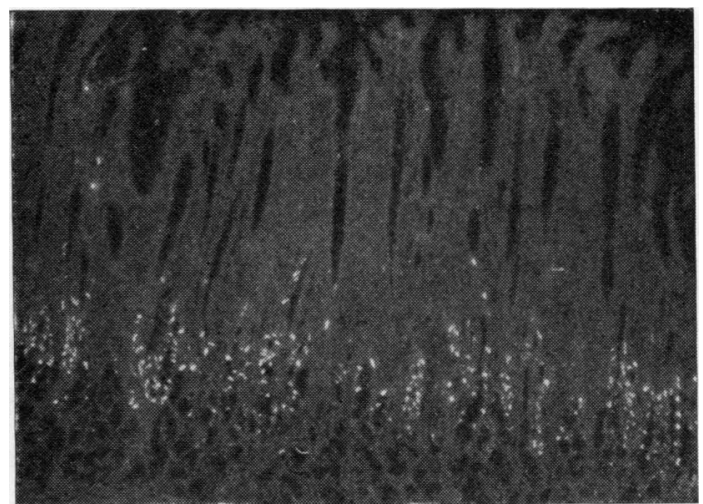

Fig. 2(b) Adjacent section to that in Fig. 2a. No marked alteration in gastrin cell numbers. Immunofluorescence $\times 60$.

Figure 5. Small numbers of gastrin cells were present within body mucosa close to the junction.

No gastrin cells were detected within histologically normal body mucosa outside the transitional zone. However, in parts of the fundus affected by pseudopyloric metaplasia occasional scattered gastrin cells were found (Fig. 6). In the presence of more severe fundal atrophic gastritis associated with intestinal metaplasia no such cells were present.

The gastric polypi were all examples of regenerative mucosal polypi occurring in the presence of severe atrophic gastritis. Both antral and fundal polypi were examined. The mucosa of the polypi showed foveolar hyperplasia (Elster, 1976), and microcysts lined by surface-type epithelium were often seen. In 


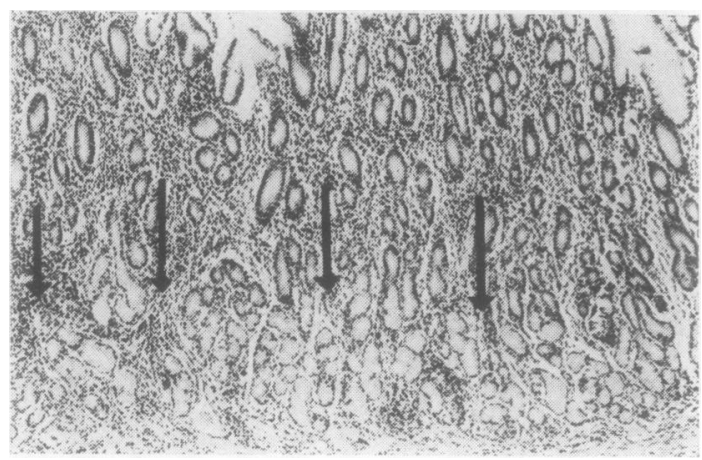

Fig. 3(a) Early atrophic gastritis in antral mucosa. Arrows indicate atrophy within glandular zone $(G)$. $H$ and $E \times 60$.

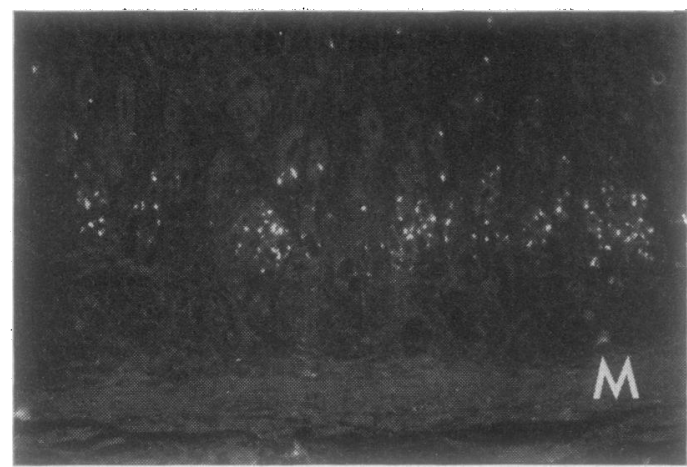

Fig. 3(b) Adjacent section to that in Fig. 3a. Patchy gastrin cell distribution at left of field in areas of glandular atrophy. Muscularis mucosae (M).

Immunofluoresence $\times 60$.

all five cases small numbers of gastrin cells were found within the hyperplastic mucosa of the polypi. The cells were usually sparse and widely scattered but occasionally large groups of cells were seen (Fig. 7). Intestinal metaplasia was sometimes seen within the polypoid mucosa, and no gastrin cells were found in such areas.

\section{Discussion}

The results indicate that immunoreactive gastrin cell numbers in the antrum are diminished in proportion to increasing severity of gastritis in the local mucosa. This supports the findings of Asnaes et al. (1976), who investigated antral mucosal biopsies and found an inverse correlation between gastrin cells and the degree of gastritis. Recently,

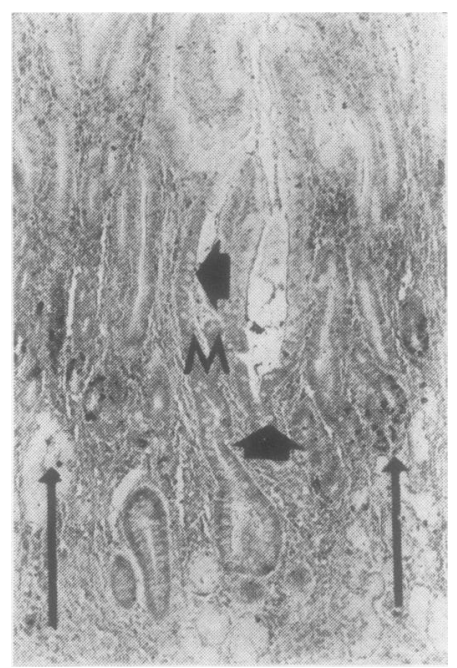

Fig. 4 Intestinal metaplasia $(M)$ with goblet cells (short arrows) in antral mucosa. Long arrows show groups of gastrin cells in adjacent normal mucosa. No gastrin cells in metaplastic area. Immunoperoxidase $\times$ 80.

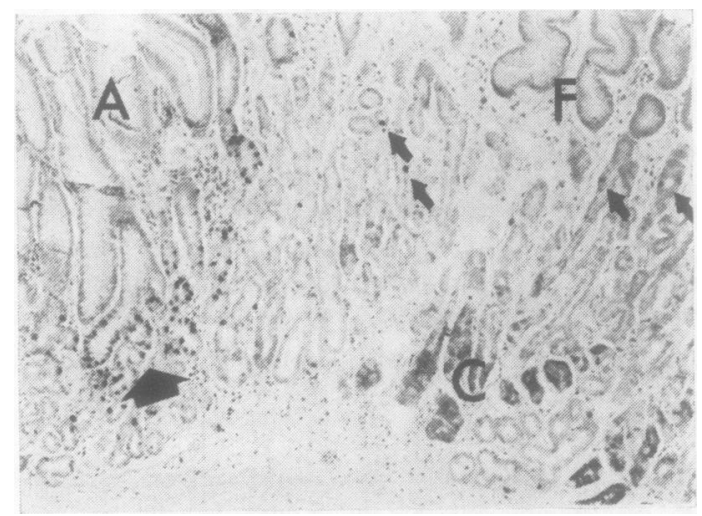

Fig. 5 Antral/fundal junction. Normal numbers of gastrin cells in antrum $(A)$ (large arrow). Small arrows show some of the gastrin cells in adjacent fundal mucosa $(F)$. Fundal chief cells $(C)$ stain darkly.

Immunoperoxidase $\times 80$.

Kueppens et al. (1978) also noted an irregular distribution of gastrin cells in antral gastritis. Stockbrügger et al. (1977) studied patients with achlorhydria and noted increased numbers of gastrin cells in antral mucosa which was not inflamed. If atrophic gastritis was present in the antrum both gastrin cell numbers and serum gastrin levels fell dramatically, while mild chronic superficial antral gastritis had no effect. 


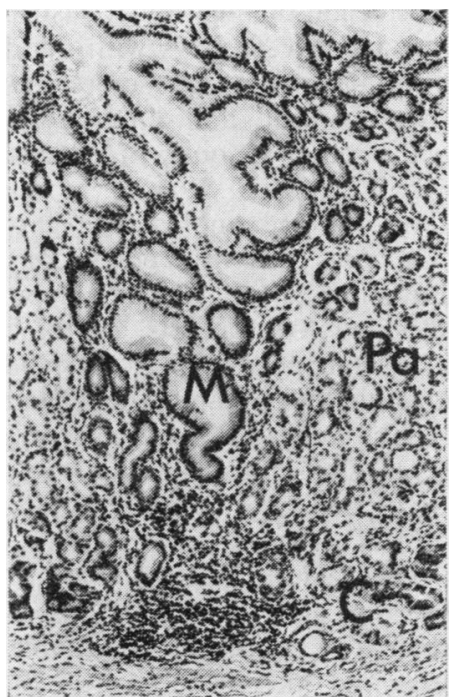

Fig. 6(a) Patch of pseudopyloric metaplasia $(M)$ in fundal mucosa surrounded by parietal cells $(P a)$. Inflammation interrupts basal zone of chief cells $(C)$. $H$ and $E \times 100$.

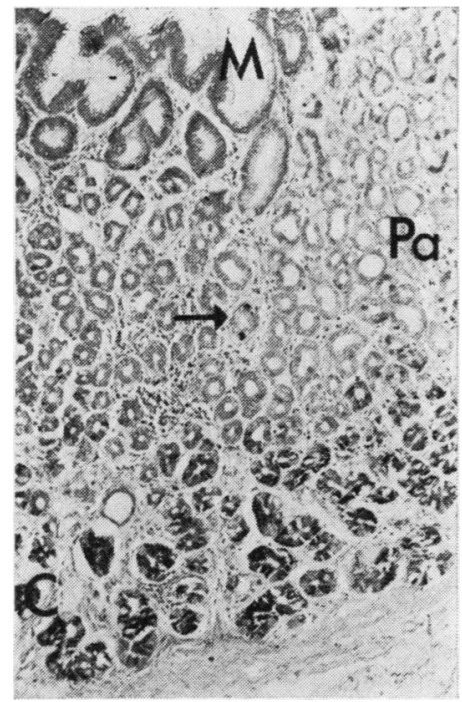

Fig. 6(b) Adjacent section to that in Fig. 6a. Two gastrin cells (arrowed) within gland in area of pseudopyloric metaplasia $(\mathrm{M})$. Parietal cells $(\mathrm{Pa})$. Chief cells $(C)$. Immunoperoxidase $\times 100$.

While the above reports and the present study indicate reduced antial gastrin cells in gastritis, neither Meikle et al. (1976) nor Fung et al. (1977)

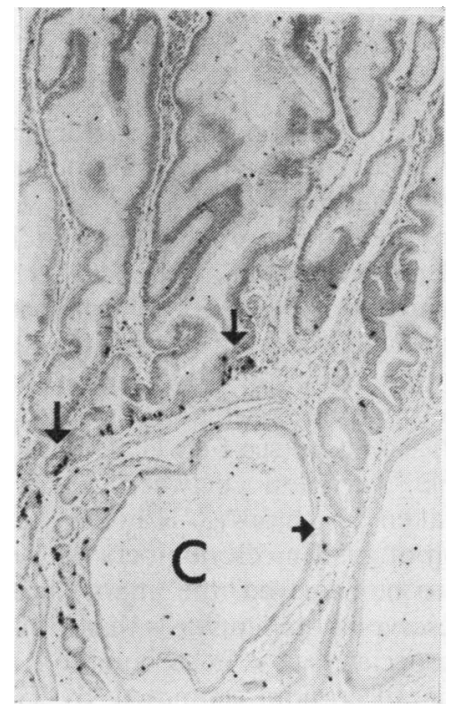

Fig. 7 Mucosa of gastric polyp. Arrows show some of the groups of gastrin cells within antral-type mucosal glands. Several microcysts $(C)$ are present.

Immunoperoxidase $\times 60$.

found any correlation between the severity of antral gastritis and circulating gastrin levels. This may be due to the fact that in most cases of antral gastritis sufficient gastrin cells remain within the antrum to maintain circulating hormone levels, and only in very widespread intestinal metaplasia are gastrin cells almost totally absent. A further explanation may be that other sites of gastrin production such as the duodenum can maintain circulating hormone levels.

Failure to stain gastrin cells by the methods used in the present study does not prove that the cells are absent. They may lose their hormone content very rapidly in the presence of inflammation and thus more cells may fail to react with the antibody.

There appears to be a closer inverse correlation between circulating gastrin levels and antral gastritis in hypergastrinaemic states such as pernicious anaemia. Strickland et al. (1971) found that patients with fundal atrophic gastritis and hypergastrinaemia had histologically normal antral mucosa. Those with atrophic gastritis of the fundus and normal serum gastrin levels showed severe involvement of the antrum as well as fundus by the inflammatory reaction.

Several authors have commented on the marked variation in gastrin cell concentration from one area of the stomach to another noted on studies on gastrectomy specimens (Delaney et al., 1978; Keuppens et al., 1978; Stave and Brandtzaeg, 1976). Similar vari- 
ations have been reported in mucosal biopsies by Pearse and Bussolati (1970), Creutzfeldt et al. (1976), and Asnaes and Johansen (1975).

This variation can be explained partly by the differing gastrin cell concentration reported within the normal antrum. Stave and Brandtzaeg (1976) noted increasing numbers of gastrin cells in the distal as opposed to the proximal antrum in patients with duodenal ulceration. Keuppens et al. (1978) did not confirm this but reported significantly more cells in sections taken from the greater curvature of the antrum than from the lesser curvature. Furthermore, in normal mucosa the distribution of gastrin cells is rather uneven (see Fig. 1). This could lead to considerable variation between small mucosal samples taken at biopsy. However, if realistic comparison of gastrin cell numbers between patient groups is to be achieved, the importance of antral gastritis deserves more emphasis than it has hitherto received, especially as it is so common in patients with peptic ulceration, as noted by Gear et al. (1971) and confirmed by Keuppens et al. (1978) and the present study. Asnaes et al. (1976) first reported the marked effect of gastritis on immunoreactive gastrin cells and stated that the cells were never found in the presence of intestinal metaplasia. We found occasional gastrin cells within areas involved by this condition but they were very rare.

The principal concentration of gastrin cells in the stomach is in the antrum. They are also found in much smaller numbers in the duodenum, jejunum, and the transitional zone of the stomach between the fundus and antrum. In the latter area small numbers of gastrin cells were found within fundal mucosa close to the junction. Apart from this we failed to find gastrin cells within histologically normal fundal mucosa. This is in agreement with the findings of Stave and Brandtzaeg (1976) and Helmstaedter et al. (1977). In the presence of pseudopyloric metaplasia within the fundus we consistently found small numbers of immunoreactive gastrin cells within the metaplastic mucosa. Polak et al. (1971, 1973) reported gastrin cells within the fundus in patients with pernicious anaemia, antral gastrin cell hyperplasia, and hypergastrinaemia but these features were not present in any of the cases in the present study. Rubin (1973) found that these fundal gastrincontaining cells resembled enterochromaffin-like cells rather than gastrin cells when studied at ultrastructural level.

Malmstrøm et al. (1976) extracted and estimated the gastrin content in mucosa from stomach, duodenum, and jejunum. They found a small amount of gastrin in fundal mucosa in all subjects examined. The origin of this fundal gastrin was not discussed, but in their patients with duodenal and gastric ulceration it is likely that some pseudopyloric metaplasia was present, and this may have contributed to the small amount of fundal mucosal gastrin found.

The finding of immunoreactive gastrin cells within the mucosa of gastric polypi was not unexpected. Both fundal and antral polypi were examined, and in all five patients gastrin cells were found within some polypi. The polypoid mucosa shows foveolar hyperplasia and resembles antral-type mucosa, and the appearance of isolated groups of gastrin cells tends to support this.

This study demonstrates a marked diminution in the demonstrable gastrin cell population in the presence of even a mild degree of antral atrophic gastritis. There is an inverse relationship between antral gastrin cell numbers detectable by the methods used and increasing severity of gastritis. On the other hand, pseudopyloric metaplasia of the fundus is associated with the appearance of small numbers of gastrin cells in an area where these cells are not normally found.

\section{References}

Ardill, J. E. S. (1973). The measurement of gastrin by radioimmunoassay. Ph.D. thesis, Queen's University, Belfast.

Asnaes, S., Bjerregaard, B., Malmström, J., Hansen, O. H., Hardt, F., and Johansen, A. (1976). Antral gastrin cells. Scandinavian Journal of Gastroenterology, 11, 471-474.

Asnaes, S., and Johansen, A. (1975). Variation in distribution of antral gastrin cells. Acta Pathologica et Microbiologica Scandinavica, 83A, 737-738.

Creutzfeldt, W., Arnold, R., Creutzfeldt, C., and Track, N. S. (1976). Mucosal gastrin concentration, molecular forms of gastrin, number and ultrastructure of G-cells in patients with duodenal ulcer. Gut, 17, 745-754.

Delaney, J. P., Michel, H. M., Eisenberg, M. M., and Bonsack, M. (1978). Quantitation of antral gastrin cell populations in the dog. Gastroenterology, 74, 708-712.

Elster, K. (1976). Histologic classification of gastric polyps. Current Topics in Pathology, 63, 77-93.

Fung, W. P., Salmon, J. A., Karim, S. M. M., Tye, C. Y., and Lee, S. K. (1977). Serum gastrin in patients with various types of chronic gastritis. American Journal of Gastroenterology, 68, 141-144.

Ganguli, P. C., Pearse, A. G. E., Polak, J. M., Elder, J. B., and Hegarty, M. (1974). Antral-gastrin-cell hyperplasia in peptic-ulcer disease. Lancet, 1, 583-586.

Gear, M. W. L., Truelove, S. C., and Whitehead, R. (1971). Gastric ulcer and gastritis. Gut, 12, 639-645.

Helmstaedter, V., Feurle, G. E., and Forssmann, W. G. (1977). Relationship of glucagon-somatostatin cells 
and gastrin-somatostatin cells in the stomach of the monkey. Cell and Tissue Research, 177, 29-46.

Joske, R. A., Finckh, E. S., and Wood, I. J. (1955). Gastric biopsy. Quarterly Journal of Medicine, 24, 269-294.

Keuppens, F., Willems, G., Vansteenkiste, Y., and Woussen-Colle, M. C. (1978). Estimation of the antral and duodenal gastrin cell population removed by gastrectomy from patients with peptic ulcer. Surgery, Gynaecology and Obstetrics, 146, 440-406.

McGuigan, J. E. (1968). Gastric mucosal intracellular localization of gastrin by immunofluorescence. Gastroenterology, 55, 315-327.

Malmstrøm, J., Stadil, F., and Rehfeld, J. F. (1976). Gastrins in tissue. Gastroenterology, 70, 697-703.

Meikle, D. D., Taylor, K. B., Truelove, S. C., and Whitehead, R. (1976). Gastric duodenitis and circulating levels of gastrin in duodenal ulcer before and after vagotomy. Gut, 17, 719-728.

Morson, B. C. (1955). Intestinal metaplasia of the gastric mucosa. British Journal of Cancer, 9, 365-376.

Pearse, A. G. E., and Bussolati, G. (1970). Immunofluorescence studies of the distribution of gastrin cells in different clinical states. Gut, 11, 646-648.

Polak, J. M., Coulling, I., Doe, W., and Pearse, A. G. E. (1971). The $\mathrm{G}$ cells in pernicious anaemia. Gut, 12, 319-323.

Polak, J. M., Hoffbrand, A. V., Reed, P. I., Bloom, S., and Pearse, A. G. E. (1973). Qualitative and quantitative studies of antral and fundic $G$ cells in pernicious anaemia. Scandinavian Journal of Gastroenterology, 8, 360-367.

Rubin, W. (1973). A fine structural characterization of the proliferated endocrine cells in atrophic gastric mucosa. American Journal of Pathology, 70, 109-114.

Siurala, M., Isokoski, M., Varis, K., and Kekki, M. (1968). Prevalence of gastritis in a rural population. Scandinavian Journal of Gastroenterology, 3, 211-223.

Stave, R. and Brandtzaeg, P. (1976). Immunohistochemical investigation of gastrin-producing cells (G cells). Scandinavian Journal of Gastroenterology, 11, 705-712.

Sternberger, L. A., Hardy, P. H., Jr., Cuculis, J. J., and Meyer, H. G. (1970). The unlabeled antibody enzyme method of immunohistochemistry. Journal of Histochemistry and Cytochemistry, 18, 315-333.

Stockbrügger, R., Larsson, L. -I., Lundqvist, G., and Angervall, L. (1977). Antral gastrin cells and serum gastrin in achlorhydria. Scandinavian Journal of Gastroenterology, 12, 209-213.

Strickland, R. G., Bhathal, P. S., Korman, M. G., and Hansky, J. (1971). Serum gastrin and the antral mucosa in atrophic gastritis. British Medical Journal, 4, 451-453.

Taylor, C. R. (1974). The nature of Reed-Sternberg cells and other malignant "reticulum" cells. Lancet, 2, 802-807.

Whitehead, R., Truelove, S. C., and Gear, M. W. L. (1972). The histological diagnosis of chronic gastritis in fibreoptic gastroscope biopsy specimens. Journal of Clinical Pathology, 25, 1-11.

Requests for reprints to: Dr J. M. Sloan, Department of Pathology, The Queen's University of Belfast, Grosvenor Road, Belfast BT12 6BL, UK 